\title{
Quantification of Plant available Zinc, Copper, Iron, Manganese, Boron, and Visualization of their Spatial Distribution through GIS in District Mandi Bahauddin, Punjab, Pakistan
}

\author{
Zahid Hassan Tarar', Muhammad Salik Ali Khan ${ }^{2 *}$, Shahzada Munawar Mehdi ${ }^{3}$, Raza Salim ${ }^{4}$, Irfan

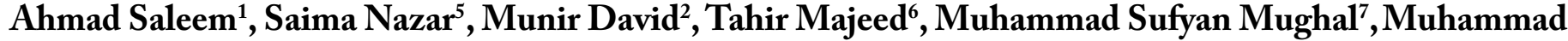 \\ Saleem $^{8}$, Umer Iqbal ${ }^{9}$, Muhammad Mazhar Iqbal ${ }^{10}$ and Muhammad Khalid Shaheen ${ }^{3}$
}

\begin{abstract}
${ }^{1}$ Soil and Water Testing Laboratory, Mandi Bahauddin, Punjab, Pakistan; ${ }^{2}$ Provincial Reference Fertilizer Testing Laboratory, Raiwind, Lahore, Pakistan; ${ }^{3}$ Soil Fertility Research Institute, Thokar Niaz Baig, Labore, Punjab, Pakistan; ${ }^{4}$ Soil and Water Testing Laboratory, Narowal, Punjab, Pakistan; ${ }^{5}$ Agricultural Officer (Field) Gujrat, Punjab, Pakistan; ${ }^{6}$ Soil and Water Testing Laboratory, Attock, Punjab, Pakistan; ${ }^{7}$ Office of Chief Engineer, Drainage and Flood Zone, Irrigation Department, Thokar Niaz Baig, Lahore, Punjab, Pakistan; ${ }^{8}$ Agricultural officer (Field), Vehari, Punjab, Pakistan; ${ }^{9}$ Scientific Officer, Crop Diseases Research Institute, NARC, Islamabad, Punjab, Pakistan.; ${ }^{10}$ Soil and Water Testing Laboratory, Chiniot, Punjab, Pakistan.
\end{abstract}

Abstract | Micronutrients deficiency in alkaline-calcareous soils is a major constraint to get optimum crop yield. The possible solution could be the site-specific nutrient management after assessing the micronutrient status at a particular site. This study was conducted to quantify and visualize the spread of plant available micronutrients in district Mandi Bahauddin. Total 1194 georeferenced soil samples were collected at a depth of $0-15 \mathrm{~cm}$ maintaining a sampling grid cell size of 10 -acres $\left(40469 \mathrm{~m}^{2}\right)$ throughout the sampling area. These samples were analyzed for plant available Zinc $(\mathrm{Zn})$, Copper $(\mathrm{Cu})$, Iron $(\mathrm{Fe})$, Manganese $(\mathrm{Mn})$ following Diethylenetriamine Penta-Acetate (DTPA) extraction methodology. Quantification was carried out by Flame Atomic Absorption Spectroscopy (AAS). Hot water-soluble (HWS) Boron (B) was determined spectrophotometrically. Additionally, soil samples were also analysed for electrical conductivity (EC), soil $\mathrm{pH}$ and soil organic matter (SOM) contents. These characteristics were correlated with plant available micronutrients. The DTPA-extractable $\mathrm{Zn}, \mathrm{Cu}, \mathrm{Fe}$, and $\mathrm{Mn}$ ranged from 0.07-5.60, 0.11-1.22, 0.74-7.45 and 0.02-3.39 mg/Kg soil, respectively. Boron ranged from $0.06-0.69 \mathrm{mg} / \mathrm{Kg}$ soil. Considering the critical limits set by National Agricultural Research Center (NARC), Islamabad, Pakistan, 92\% soil samples were found deficient in B followed by 44\% soil samples low in Fe. Whereas, $\mathrm{Zn}, \mathrm{Cu}$ and $\mathrm{Mn}$ were deficient in 5, 1 and 12 $\%$ of soil samples, respectively. Soil $\mathrm{EC}$ and $\mathrm{pH}$ of analysed samples ranged from 0.10 to $3.74 \mathrm{dSm}^{-1}$ and 6.70 to 8.40 , respectively. Soil was free from salinity and sodicity menace. However, soil was deficient regarding $\mathrm{SOM}$ with mean value of $0.69 \%$. The correlations between soil $\mathrm{pH}$ and plant available $\mathrm{Zn}, \mathrm{Fe}, \mathrm{Mn}$, and $\mathrm{B}$ were significant and negative. The ordinary kriging technique was used to assess the micronutrient status at non-sampling sites and research area was classified into low, marginal, and adequate categories according to plant available micronutrient status. Digital maps thus developed using Quantum Geographic Information System (QGIS) would help to apply micronutrients more precisely and site-specifically.

Received | January 07, 2020; Accepted | July 07, 2020; Published | August 01, 2020

*Correspondence | Muhammad Salik Ali Khan, Provincial Reference Fertilizer Testing Laboratory, Raiwind, Lahore, Pakistan; Email: msalikali786@gmail.com

Citation | Tarar, Z.H., M.S.A. Khan, S.M. Mehdi, R. Salim, I.A. Saleem, S. Nazar, M. David, T. Majeed, M.S. Mughal,M. Saleem, U. Iqbal, M.M. Iqbal and M.K. Shaheen. 2020. Quantification of plant available zinc, copper, iron, manganese, boron, and visualization of their spatial distribution through GIS in district Mandi Bahauddin, Punjab, Pakistan. Pakistan Journal of Agricultural Research, 33(3): 609-618.

DOI | http://dx.doi.org/10.17582/journal.pjar/2020/33.3.609.618

Keywords | DTPA-extractable Zn, DTPA-extractable Cu, DTPA-extractable Fe, DTPA-extractable Mn, Hot water-soluble B, Digital maps

September 2020 | Volume 33 | Issue 3 | Page 609 
Introduction

$\mathrm{R}$ apidly increasing world population urges the need to increase the food production up to $50 \%$ of existing quantity till the end of 2025 (Rengel, 1999; Fisk et al., 2015). This scenario necessitates the intensive farming system on sustainable basis. One of the key factors for sustainability is to maintain soil fertility status at an optimum level. Deficiency of plant nutrients could reduce yield and quality of agricultural produce. Plant nutrients are categorized into two fair groups of macronutrients and micronutrients (Marschner, 2012). Micronutrients are mineral elements, present in much lower concentrations in plants as compared to macronutrients. However, these are as important as macronutrients (Marschner, 2012). These micronutrients are further categorized based on their essentiality for plants. The essential micronutrients are (1) directly involved in plant metabolism, (2) their function must not be replaced by another element and (3) in the absence of essential micronutrient, plant is unable to complete its life cycle (Arnon and Stout, 1939). Essential micronutrients such as iron $(\mathrm{Fe})$, Manganese $(\mathrm{Mn})$, Copper $(\mathrm{Cu})$ and Molybdenum (Mo) serve as part of metalloproteins and catalyze redox processes through electron transfer. Some micronutrients (e.g. Fe and $\mathrm{Zn}$ ) also make enzyme-substrate complex and speed up the reaction by affecting the molecular configuration of enzyme or substrate (Mortvedt et al., 1991).

Boron is an essential metalloid, having properties intermediate between metals and non-metals. Boron is involved in sugar transport, synthesis of cell wall, lignification, carbohydrate, and RNA metabolism. Pollen tube and pollen germination in crops is also linked with boron (Marschner, 2012).

Micronutrients exist in soil in different forms. These may be water-soluble, exchangeable, chelated or in complexed form with organic molecules. Metal oxides or elements within crystal lattice of secondary clay minerals are usually insoluble. Furthermore, inorganic metallic compounds are generally readily plantavailable than insoluble organically bonded metals (Bell et al., 1991). Soil physio-chemical characteristics such as soil organic matter (SOM) and soil reaction $(\mathrm{pH})$ influence plant availability of micronutrients. Soil organic matter makes metal-organic complex and can increase or decrease metals availability depending on the stability constant value of metal- organic complex. Metals have different affinity level for SOM, hence the different stability constant value of metal-organic complex. For instance, cadmium (Cd) extraction from $\mathrm{Cd}$-organic complex is easier (low stability constant) than extracting $\mathrm{Cu}$ from $\mathrm{Cu}-$ organic complex (high stability constant). Whereas, Nickel $(\mathrm{Ni})$ and $\mathrm{Zn}$ have relative low affinity with SOM and can be easily extracted from their respective organic complexes (Narwal and Singh, 1998). Likewise, functional groups differ in affinity with metal elements. Enolate (dissociated phenolic $-\mathrm{OH}$, O-) group has highest affinity for metal elements whereas carbonyl $(\mathrm{C}=\mathrm{O})$ group has least (Cresser et al., 1993). Generally, long chain organics e.g. lignin make strong, insoluble metal-complex and reduce metal extraction as compared to simple organics.

Soil $\mathrm{pH}$ has direct and indirect effect on metal elements extraction. Soil $\mathrm{pH}$ changes metals speciation and their oxidation states. e.g. $\mathrm{Cu}$ can be found as $\mathrm{Cu}^{2+}$ and $\mathrm{CuOH}^{+}$depending upon the $\mathrm{pH}$ conditions. In acidic medium, $\mathrm{Zn}$ exist in $\mathrm{Zn}^{2+}$ form and at alkaline conditions the predominant form is $\mathrm{ZnOH}^{+}$. The solubility of $\mathrm{Zn}$ can decrease 100 folds with a unit increase in $\mathrm{pH}$ (Tisdale et al., 1985). Likewise, $\mathrm{Cu}$ and cobalt are much soluble at lower $\mathrm{pH}$ and may flush out with drainage water (Cresser et al., 1993). As an indirect effect, soil $\mathrm{pH}$ changes polarity on exchange sites. Soil $\mathrm{pH}$-dependent charge on exchange sites effects adsorption or release of metal elements. Furthermore, alkaline conditions favours Fe-Mn oxides which bound with metal elements reducing their extractability (Bell et al., 1991; Narwal and Singh, 1998).

Pakistan has generally alkaline-calcareous soils having $\mathrm{pH}$ ranging from 7.5 to 8.5 (Rashid et al., 1997; Bashir and Bantel, 2005). This alkaline $\mathrm{pH}$ reduces the solubility of micronutrients in soil solution resultantly micronutrients precipitate and become unavailable to plants (Khan et al., 2010, 2013). Although micronutrient deficiency is reported world widely however,limited research work is carried out in Pakistan to assess soil micronutrient status of agricultural land (Ahmed et al., 2014). A survey conducted in tehsil Murree showed that 38\% of surveyed soils are deficient in plant available $\mathrm{Zn}$. Likewise, $26.6 \%$ and $80 \%$ sites are deficient in $\mathrm{Zn}$ and $\mathrm{B}$ in district Bhimber of Azad Jammu and Kashmir respectively (Nazif et al., 2006) and (Ahmad et al., 2010). District Jhelum and Chakwal are also deficient in B as 50\% 
of 140 sampled fields in Jhelum and 115 fields in Chakwal were deficient in Boron (Rashid et al., 1997).

This research work was conducted in district Mandi Bahauddin to investigate the status of micronutrients in soil. Mandi Bahauddin is located in central Punjab, between river Jhelum and Chenab and falls under arid climatic zone. The weather is hot in summer ranging up to $48^{\circ} \mathrm{C}$ while cold in winter when temperature falls as low as $5^{\circ} \mathrm{C}$. Soil is fertile in nature (Khalil-urRehman et al., 2009).

The objectives of this research work were to; (I) quantify plant-available micronutrients in the soil of district Mandi Bahauddin following DTPA extraction methodology and (II) developing digital maps illustrating micronutrient spatial distribution by using Geographic Information System (GIS). The spatial variability thus obtained would help to monitor and adjust the micronutrient application rate at a specific site (Khan et al., 2018; Meena et al., 2006).

\section{Materials and Methods}

\section{Soil sampling}

The study area was divided into a uniform grid size of 10 -acres $\left(40469 \mathrm{~m}^{2}\right)$. Soil samples were collected from each grid at a soil depth of $0-15 \mathrm{~cm}$ and their locations were noted as latitude and longitude values (GOP, 2018). Sampling area lies from $32.11910 \mathrm{~N}$ to $32.95812 \mathrm{~N}$ and 73.13194 to 74.42876 E. Sampling points were overlaid on map of district Mandi Bahauddin and represented in Figure 1. Soil samples were air dried, crushed with a wooden pestle and mortar and sieved through $2 \mathrm{~mm}$ sieve. Soil characteristics such as electrical conductivity (EC), soil $\mathrm{pH}, \mathrm{SOM}$ and soil texture were determined and then evaluated by following methodology and critical limit described by NARC, Islamabad (Ryan et al., 2001).

\section{DTPA metal-extraction: Principle and protocol}

The DTPA extraction solution as described by Lindsay and Norvell (1978) has been calibrated for soils having neutral to alkaline $\mathrm{pH}$. The soils of Pakistan are mostly alkaline in nature (Bashir and Bantel, 2005). Therefore, DTPA extraction methodology was considered suitable for quantification of plantavailable micronutrients in alkaline soils of Pakistan. Diethylenetriamine Penta-Acetate (DTPA) was used as chelating agent which can effectively bind with water-soluble and weakly adsorbed exchangeable metals in soil. The chelation reactions are slow and requires weeks or months to attain the equilibrium state. Therefore, DTPA quantity in solution-to-soilratio $(2: 1)$ was adjusted at a level that can chelate metals equal to 10 times of atomic weight of respective metals. This will potentially reduce the competition between metals ions to bind with chelating agent. Calcium Chloride $\left(\mathrm{CaCl}_{2}\right)$ maintains higher $\mathrm{CO}_{2}$ level in soil and avoid the release of metals bonded with $\mathrm{CaCO}_{3}$ by inhibiting dissolution of $\mathrm{CaCO}_{3}$ in calcareous soils. A pH around 7.3 favours formation of the Metal-DTPA complex. Triethanolamine (TEA) functions to buffer the $\mathrm{pH}$ at 7.3 and it does not interfere with flame during chemical analysis by AAS (Lindsay and Norvell, 1978).

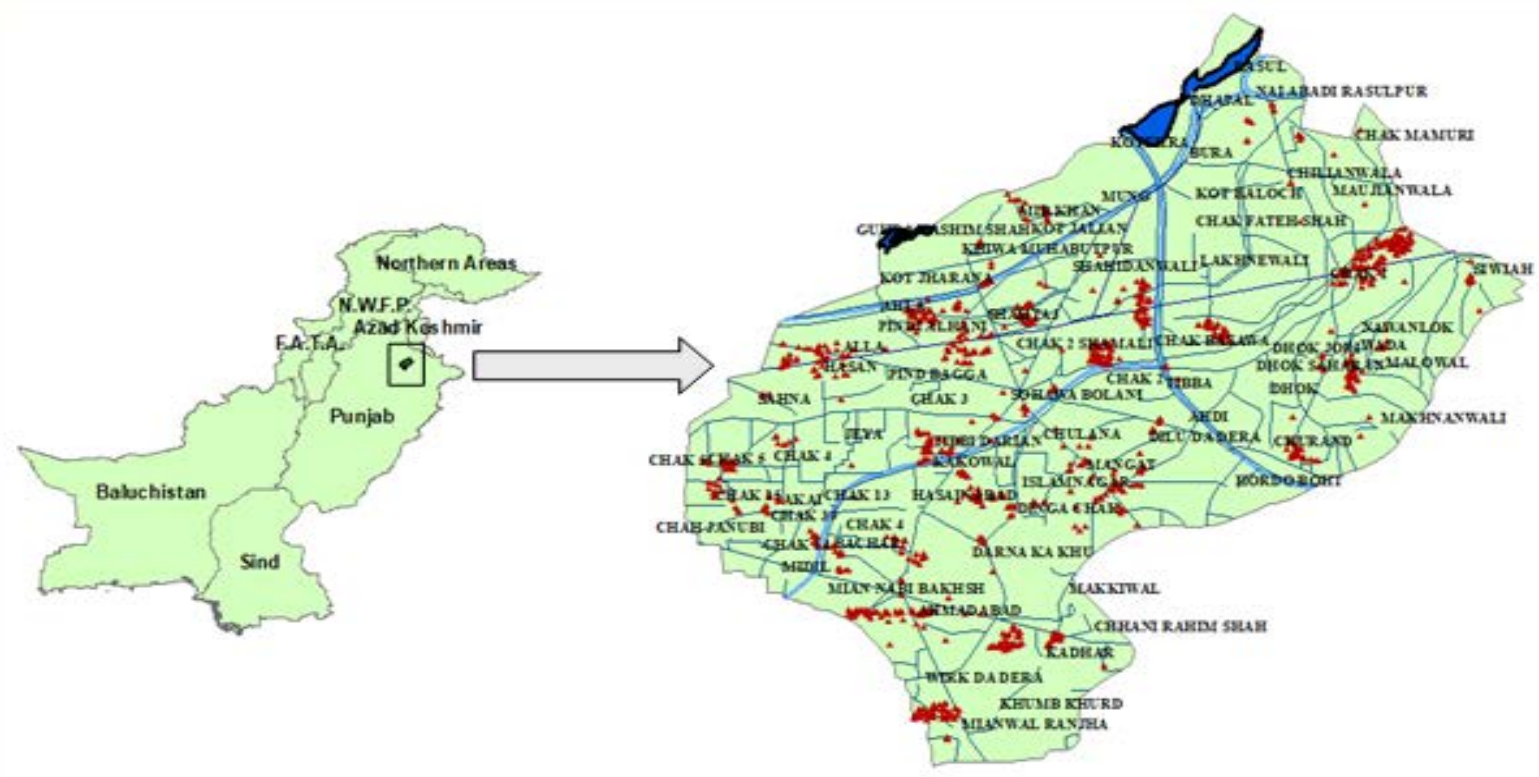

Figure 1: Location Map showing soil sampling points (red dots) in district Mandi Bahauddin. 
Extractant solution was prepared by mixing $0.005 \mathrm{M}$ DTPA, $0.01 \mathrm{M} \mathrm{CaCl}_{2}$ and $0.10 \mathrm{M}$ triethanolamine (TEA). The $\mathrm{pH}$ of solution was maintained at 7.3. Soil sample and extractant solution in a ratio of $1: 2$ was agitated for two hours at $25^{\circ} \mathrm{C}$ and filtered using Whatman ${ }^{\circledast}$ grade 42 filter paper. Filtrate was used for determination of metal elements using Atomic Absorption Spectroscopy (AAS). Standard solutions for micronutrients $(\mathrm{Zn}, \mathrm{Cu}, \mathrm{Fe}, \mathrm{Mn})$ were prepared in DTPA extraction solution using Certified Reference Material (CRMs) traceable to National Institute of Standards and Technology (NIST). Atomic Absorption Spectrophotometer was calibrated using standard solution following the operating manual of instrument.

Boron was extracted from soil by hot-water extraction method and analyzed colorimetrically using Azomethine-H salt (William-Horwitz, 2005). The DTPA-extracted micronutrients are used to estimate the micronutrient fertility of soils (Rayment and Lyons, 2011) hence results were used to differentiate the soils as low, marginal and adequate regarding plant available micronutrients after comparing with standards set by National Agricultural Research Center (NARC), Islamabad, Pakistan (Ryan et al., 2001).

\section{Spatial distribution maps}

Georeferenced (latitude, longitude) values of collected soil samples under projected coordinated system WGS 1984 UTM: Zone 43 were used to represent the corresponding low, marginal or adequate concentration of plant available micronutrients. Data files were saved as comma-delimited text file and then imported to Quantum Geographic Information System (QGIS, v.3.12) to perform ordinary kriging and predicting the micronutrient status at nonsampling sites. Kriging is a geostatistical analysis technique based on linear interpolation. It provides the best linear estimates of non-sampling sites. The points closer to sampling site would have higher weights as compared to farthest point (Cressie, 1990). Finally, kriged maps were classified on the basis of micronutrient criteria set by Ryan et al. (2001).

A correlation study was also conducted to determine the relationship between soil basic characteristics (soil $\mathrm{pH}$ and SOM) and plant available micronutrients. The $\mathrm{R}$ statistical package (Ihaka and Gentleman, 1996) was used to determine the correlation and drawing the graphics.

\section{Results and Discussion}

\section{Plant available zinc}

Zinc concentration ranged from 0.07 to $5.60 \mathrm{mg} \mathrm{Zn/}$ $\mathrm{Kg}$ soil (Table 1). Most of the samples (87\%) were in adequate category whereas $5 \%$ samples were low in plant available $\mathrm{Zn}$ (Table 2). Analysis data revealed that overall agricultural land of district Mandi Bahauddin was adequate regarding plant available $\mathrm{Zn}$ however, localized $\mathrm{Zn}$ deficiency on the eastern and south western side of district Mandi Bahauddin is evident from spatial distribution map of $\mathrm{Zn}$ (Figure 2).

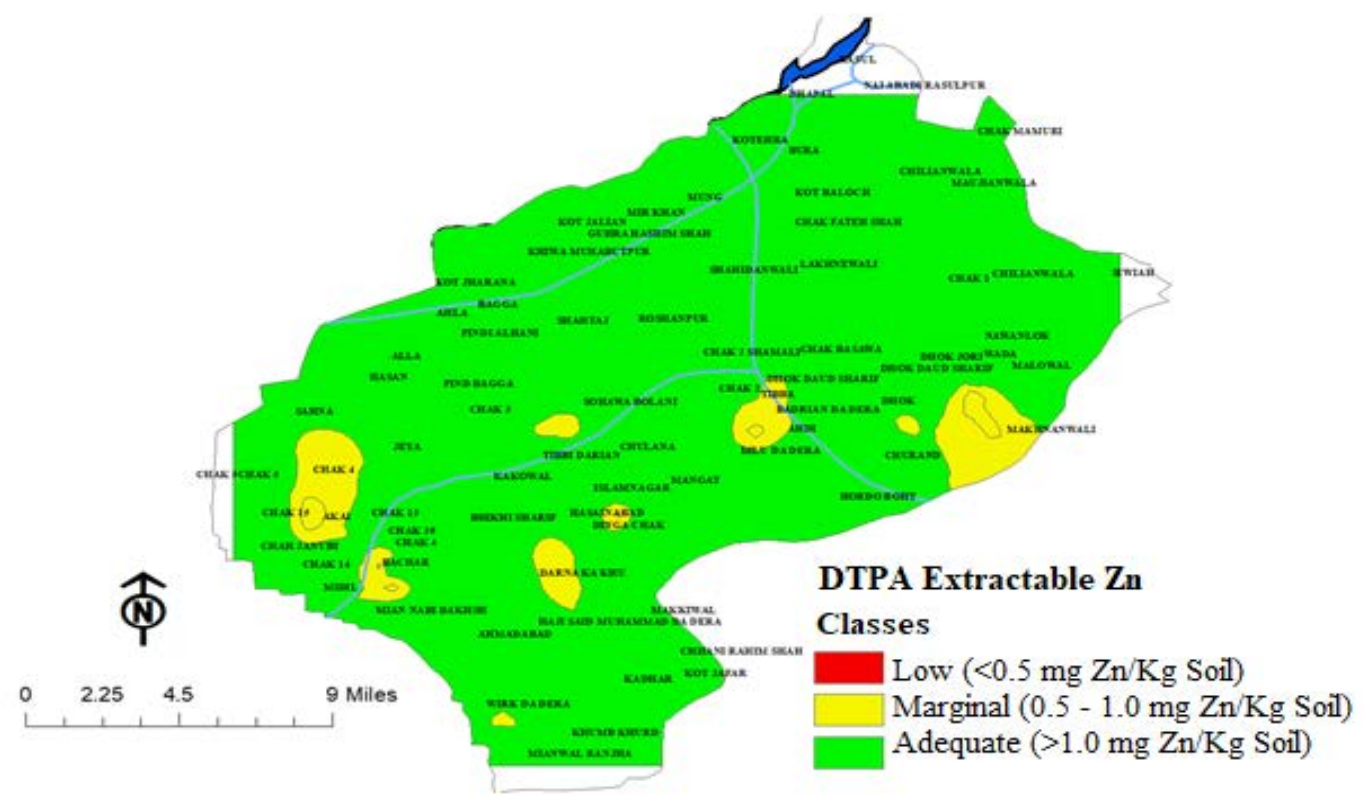

Figure 2: Distribution pattern of DTPA-extractable zinc in district Mandi Bahauddin. 
Table 1: Range, mean and standard deviation of Soil $\mathrm{pH}$ is in normal range and did not hamper $\mathrm{Zn}$ micronutrients at Mandi Bahauddin.

$\begin{array}{lllll}\begin{array}{l}\text { Micronutrient (mg/ } \\ \text { Kg) }\end{array} & \begin{array}{l}\text { Mini- } \\ \text { mum }\end{array} & \begin{array}{l}\text { Maxi- } \\ \text { mum }\end{array} & \text { Mean } & \begin{array}{l}\text { Standard } \\ \text { deviation }\end{array} \\ \text { Zinc }(\mathrm{Zn}) & 0.07 & 5.60 & 2.21 & \pm 0.77 \\ \text { Copper }(\mathrm{Cu}) & 0.11 & 1.22 & 0.45 & \pm 0.14 \\ \text { Iron }(\mathrm{Fe}) & 0.74 & 7.45 & 4.45 & \pm 0.86 \\ \text { Manganese }(\mathrm{Mn}) & 0.02 & 3.39 & 2.14 & \pm 0.74 \\ \text { Boron }(\mathrm{B}) & 0.06 & 0.69 & 0.37 & \pm 0.09\end{array}$

Table 2: Critical limits of soil $p H$, electrical conductivity, soil organic matter, DTPA-extractable zinc, copper, iron, manganese, and hot water-soluble boron and their relative frequency distribution in agricultural land of Mandi Bahauddin.

\begin{tabular}{|c|c|c|c|c|}
\hline \multirow[t]{2}{*}{ Parameter } & \multirow[t]{2}{*}{$\begin{array}{l}\text { Class } \\
\text { Interval* }^{*}\end{array}$} & \multicolumn{2}{|c|}{$\begin{array}{l}\text { Relative frequen- } \\
\text { cy distribution }\end{array}$} & \multirow[t]{2}{*}{ Status } \\
\hline & & n (1194) & $(\%)$ & \\
\hline \multirow{3}{*}{$\begin{array}{l}\text { Zinc }(\mathrm{Zn}) \\
(\mathrm{mg} / \mathrm{Kg} \text { soil })\end{array}$} & $<0.50$ & 63 & 5 & Low \\
\hline & $0.5-1.0$ & 96 & 8 & Marginal \\
\hline & $>1.0$ & 1035 & 87 & Adequate \\
\hline \multirow{3}{*}{$\begin{array}{l}\text { Copper }(\mathrm{Cu}) \\
(\mathrm{mg} / \mathrm{Kg} \text { soil })\end{array}$} & $<0.20$ & 6 & 1 & Low \\
\hline & $0.20-0.50$ & 887 & 74 & Marginal \\
\hline & $>0.50$ & 301 & 25 & Adequate \\
\hline \multirow{3}{*}{$\begin{array}{l}\text { Iron (Fe) } \\
(\mathrm{mg} / \mathrm{Kg} \text { soil) }\end{array}$} & $<4.5$ & 520 & 44 & Low \\
\hline & - & - & - & Marginal \\
\hline & $>4.5$ & 674 & 56 & Adequate \\
\hline \multirow{3}{*}{$\begin{array}{l}\text { Manganese (Mn) } \\
\text { (mg/Kg soil) }\end{array}$} & $<1.0$ & 143 & 12 & Low \\
\hline & $1.0-2.0$ & 20 & 2 & Marginal \\
\hline & $>2.0$ & 1031 & 86 & Adequate \\
\hline \multirow{3}{*}{$\begin{array}{l}\text { Boron (B) } \\
\text { (mg/Kg soil) }\end{array}$} & $<0.5$ & 1095 & 92 & Low \\
\hline & $0.5-1.0$ & 99 & 8 & Marginal \\
\hline & $>1.0$ & 0 & 0 & Adequate \\
\hline \multirow[t]{2}{*}{$\mathrm{pH}$} & $<8.4$ & 1194 & 100 & Normal \\
\hline & $>8.4$ & Nil & Nil & Sodic \\
\hline \multirow[t]{2}{*}{$\mathrm{EC}(\mathrm{dS} / \mathrm{m})$} & $<4$ & 1194 & 100 & Normal \\
\hline & $>4$ & Nil & Nil & Saline \\
\hline \multirow{3}{*}{$\begin{array}{l}\text { Soil organic mat- } \\
\text { ter (\%) }\end{array}$} & $<0.86$ & 1170 & 98 & Low \\
\hline & $0.86-1.29$ & 24 & 2 & Marginal \\
\hline & $>1.29$ & Nil & Nil & Adequate \\
\hline
\end{tabular}

Source: (Ryan et al. 2001).

Our results are contrary to the findings of Zia et al. (2006) who has reported a widespread deficiency of $\mathrm{Zn}$ across the country after analyzing 329 soil samples. The possible reason of adequate availability of $\mathrm{Zn}$ in the study area of Mandi Bahauddin could be the normal nature of its soils. The soils of Mandi Bahauddin are free from sodicity and salinity problem. availability.

\section{Plant available copper}

Plant available $\mathrm{Cu}$ ranged from 0.11 to $1.22 \mathrm{mg} \mathrm{Cu} /$ $\mathrm{Kg}$ soil (Table 1). Most of the samples (74\%) were in marginal category whereas $25 \%$ samples were adequate in plant available $\mathrm{Cu}$. Only 6 sampling sites ( $1 \%$ soil samples) were low in available $\mathrm{Cu}$ (Table 2). Spatial distribution map of $\mathrm{Cu}$ depicts the spot of adequate $\mathrm{Cu}$ on the southeastern side of district Mandi Bahauddin (Figure 3).

\section{Plant available iron}

Plant available Fe ranged from 0.74 to $7.45 \mathrm{mg} \mathrm{Fe} /$ $\mathrm{Kg}$ soil with mean value of $4.45 \mathrm{mg} \mathrm{Fe} / \mathrm{Kg}$ (Table 1). Analysis data revealed that $44 \%$ soil samples were low in Fe whereas 56\% samples were adequate (Table 2). Spatial distribution map of Fe generally depicts that northern side of district Mandi Bahauddin was adequate whereas southern side is low in $\mathrm{Fe}$ (Figure 4).

Table 3: Soil characteristics which affect plant availability of micronutrients.

\begin{tabular}{|c|c|c|c|c|}
\hline Soil Parameter & $\begin{array}{l}\text { Mini- } \\
\text { mum }\end{array}$ & $\begin{array}{l}\text { Max- } \\
\text { imum }\end{array}$ & Mean & $\begin{array}{l}\text { Standard } \\
\text { deviation }\end{array}$ \\
\hline $\begin{array}{l}\text { Electrical conductivity (EC } \\
\left.\mathrm{dSm}^{-1}\right)\end{array}$ & 0.10 & 3.74 & 1.02 & \pm 0.34 \\
\hline Soil reaction $(\mathrm{pH})$ & 6.70 & 8.40 & 7.89 & \pm 0.16 \\
\hline Soil organic matter (SOM \%) & 0.31 & 0.93 & 0.69 & \pm 0.09 \\
\hline Texture & \multicolumn{4}{|c|}{ Sandy loam to loam } \\
\hline
\end{tabular}

Table 4: Correlation coefficient (Pearson) values between soil pH and DTPA-extractable zinc, copper, iron, manganese, and boron.

Soil charac- Micronutrients

$\begin{array}{llllll}\text { teristics } & \text { Zn } & \text { Cu } & \text { Fe } & \text { Mn } & \text { B } \\ \text { Soil } \mathrm{pH} & -0.26 & \mathrm{~ns} & -0.19 & -0.28 & -0.19 \\ & \mathrm{R}^{2}= & & \mathrm{R}^{2}= & \mathrm{R}^{2}= & \mathrm{R}^{2}= \\ & 0.07^{* * *} & & 0.04^{* * *} & 0.07^{* * *} & 0.04^{* * *} \\ \text { Soil organic } & \mathrm{ns} & \mathrm{ns} & \mathrm{ns} & \mathrm{ns} & -0.09 \\ \text { matter } & & & & & \mathrm{R}^{2}= \\ & & & & & 0.008^{* *}\end{array}$

Ns: non-significant correlation coefficient; ${ }^{*} P<0.1 ;{ }^{* * *} p<0.05$; $* * 0.01$.

\section{Plant available manganese}

Manganese concentration ranged from 0.02 to 3.39 $\mathrm{mg} \mathrm{Mn} / \mathrm{Kg}$ soil with mean value of 2.14 (Table 1 ). Most of the samples (86\%) were in adequate category whereas 143 sampling sites (12\% samples) were low 
in plant available $\mathrm{Mn}$ (Table 2). Considering spatial low and 8\% were marginal regarding water-soluble distribution, the low $\mathrm{Mn}$ spots were found in the southern side of district Mandi Bahauddin. These low Mn sites exist in villages namely Kadhar, Sohawa Bolani, Bhachar, and Malkanwal (Figure 5).

\section{Plant available boron}

Boron (B) concentration ranged from 0.06 to 0.69 $\mathrm{mg} \mathrm{kg}{ }^{-1}$ soil with mean value of $0.37 \pm 0.09$ (Table 1). Analysis data showed that $92 \%$ soil samples were B (Table 2). Boron assessment of study area revealed its extensive deficiency in cultivated fields of district Mandi Bahauddin. Our results are consistent with the findings of Rashid et al. (1997) who has reported a widespread deficiency of $\mathrm{B}$ in Potohar plateau in Pakistan. Nazif et al. (2006) has also reported the B deficiency in soils of Azad Jammu and Kashmir. Spatial distribution map of B depicts its widespread deficiency in the whole district (Figure 6).

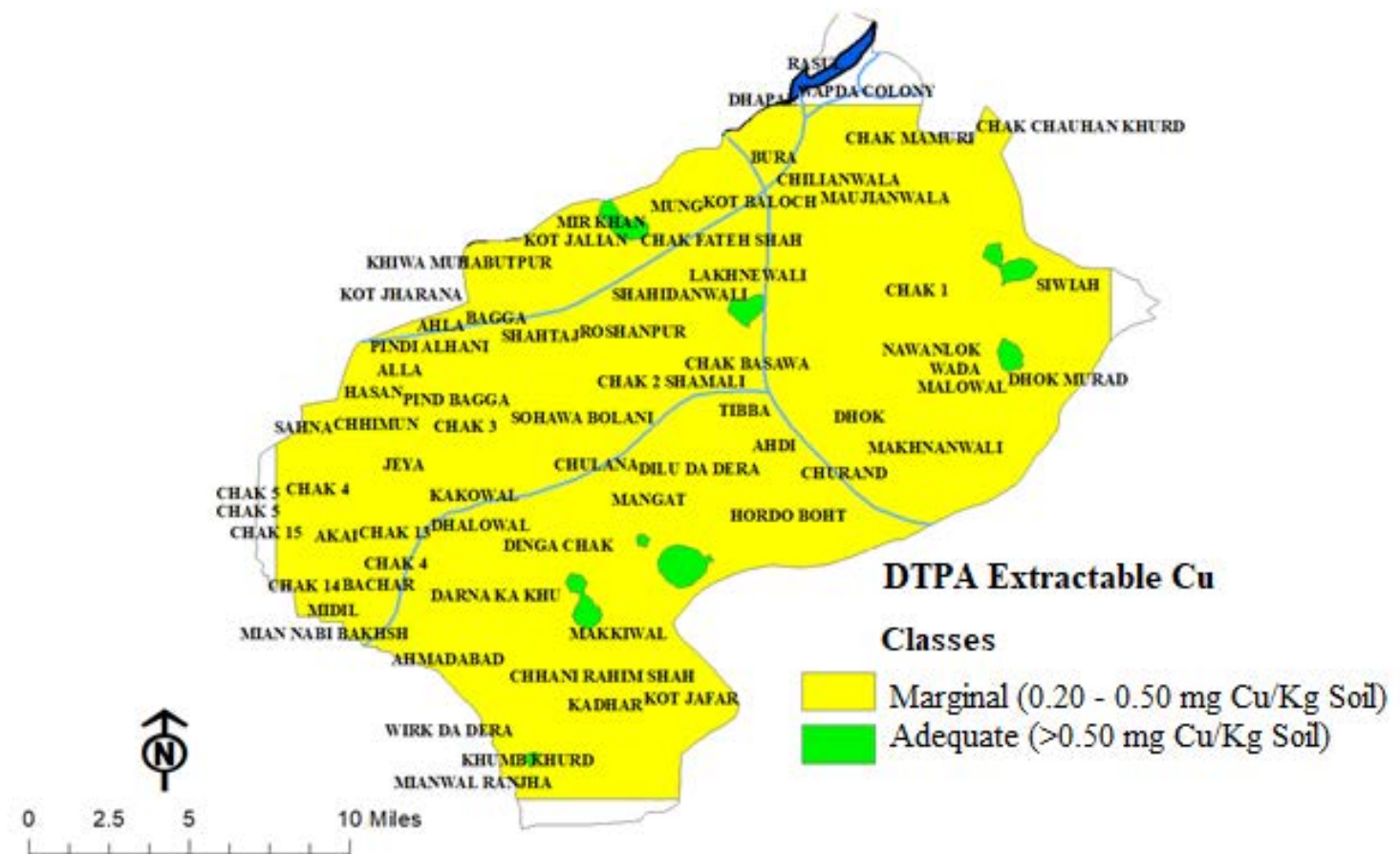

Figure 3: Distribution pattern of DTPA-extractable copper in district Mandi Bahauddin.

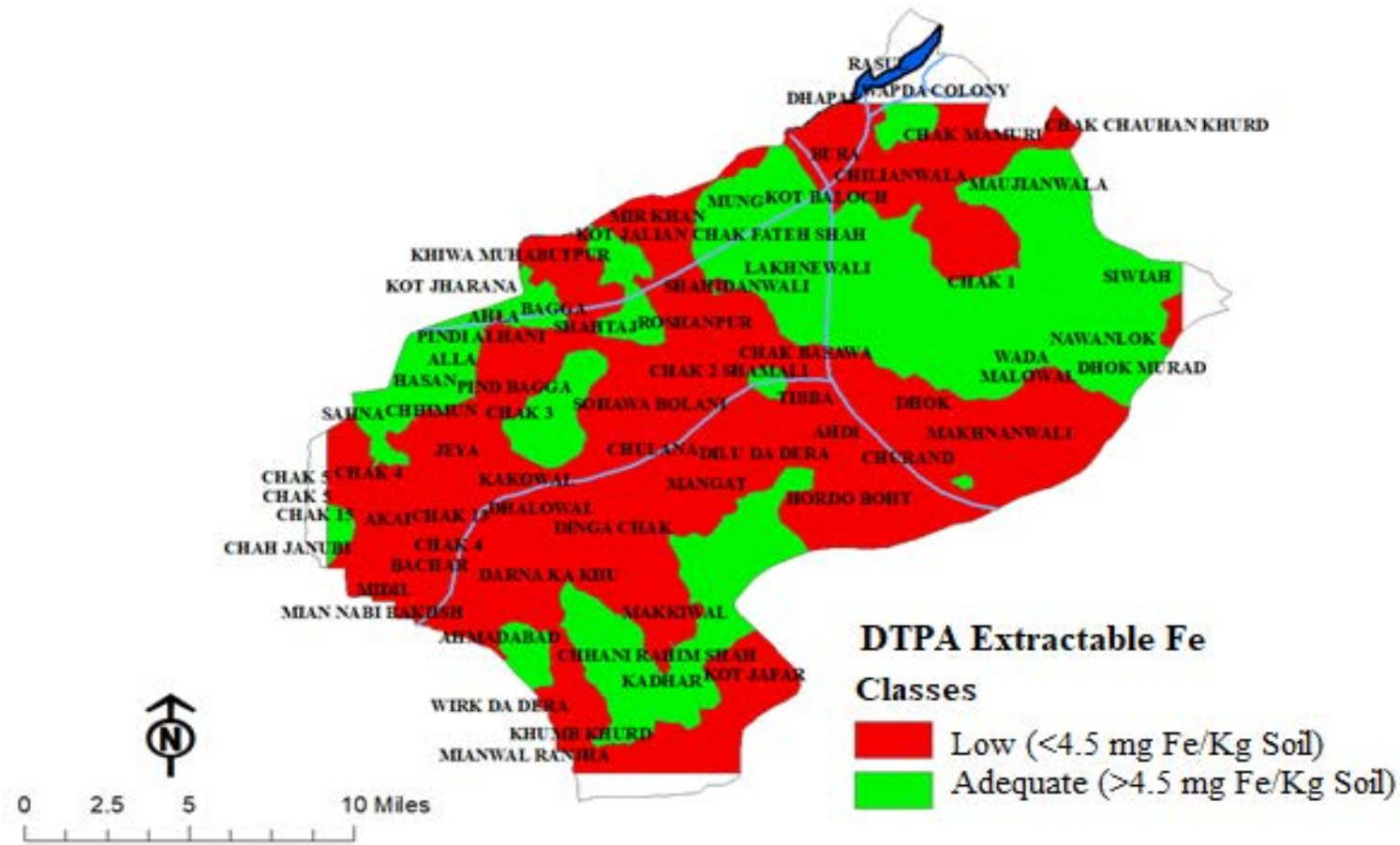

Figure 4: Distribution pattern of DTPA-extractable iron in district Mandi Bahauddin. 


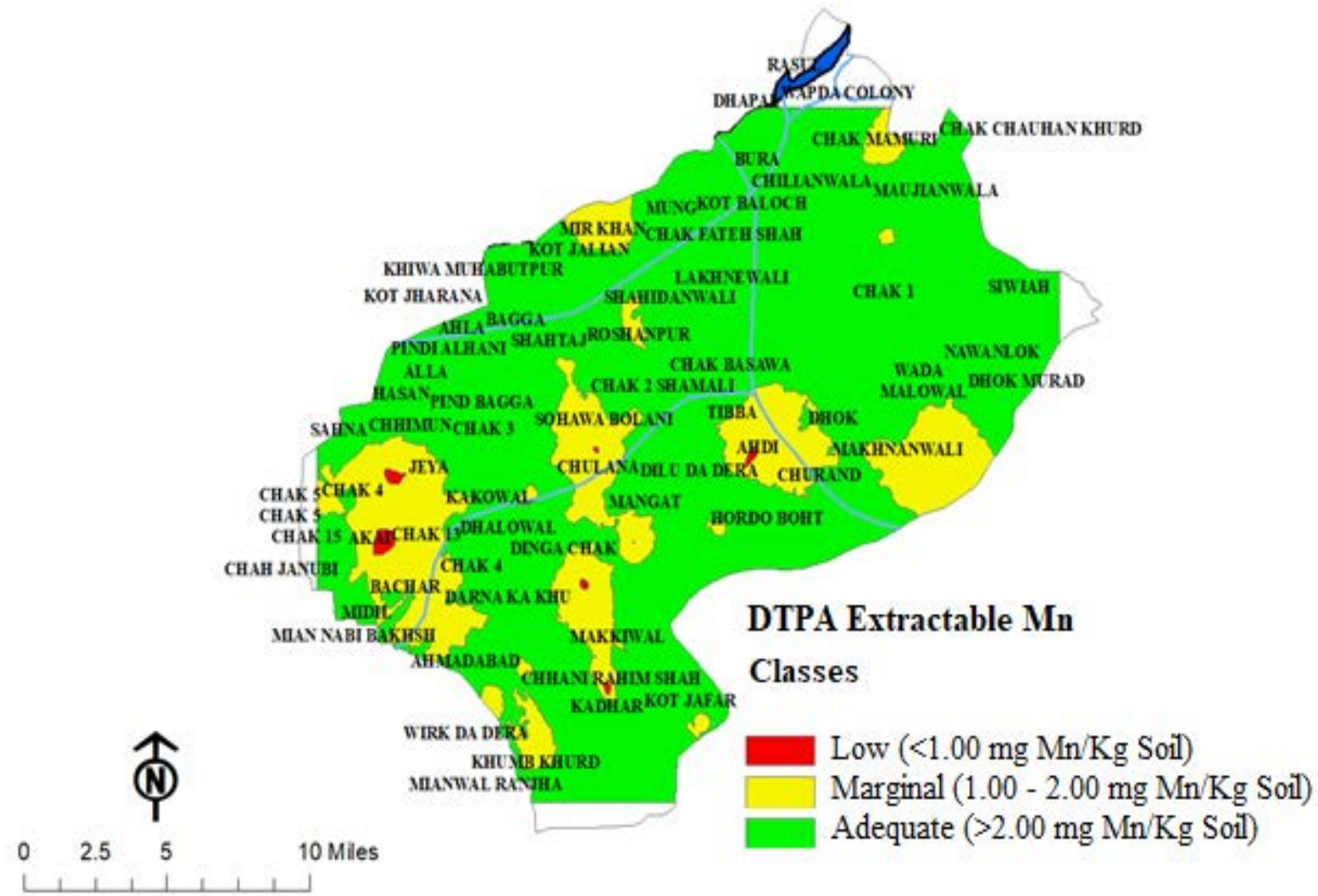

Figure 5: Distribution pattern of DTPA-extractable manganese in district Mandi Babauddin.

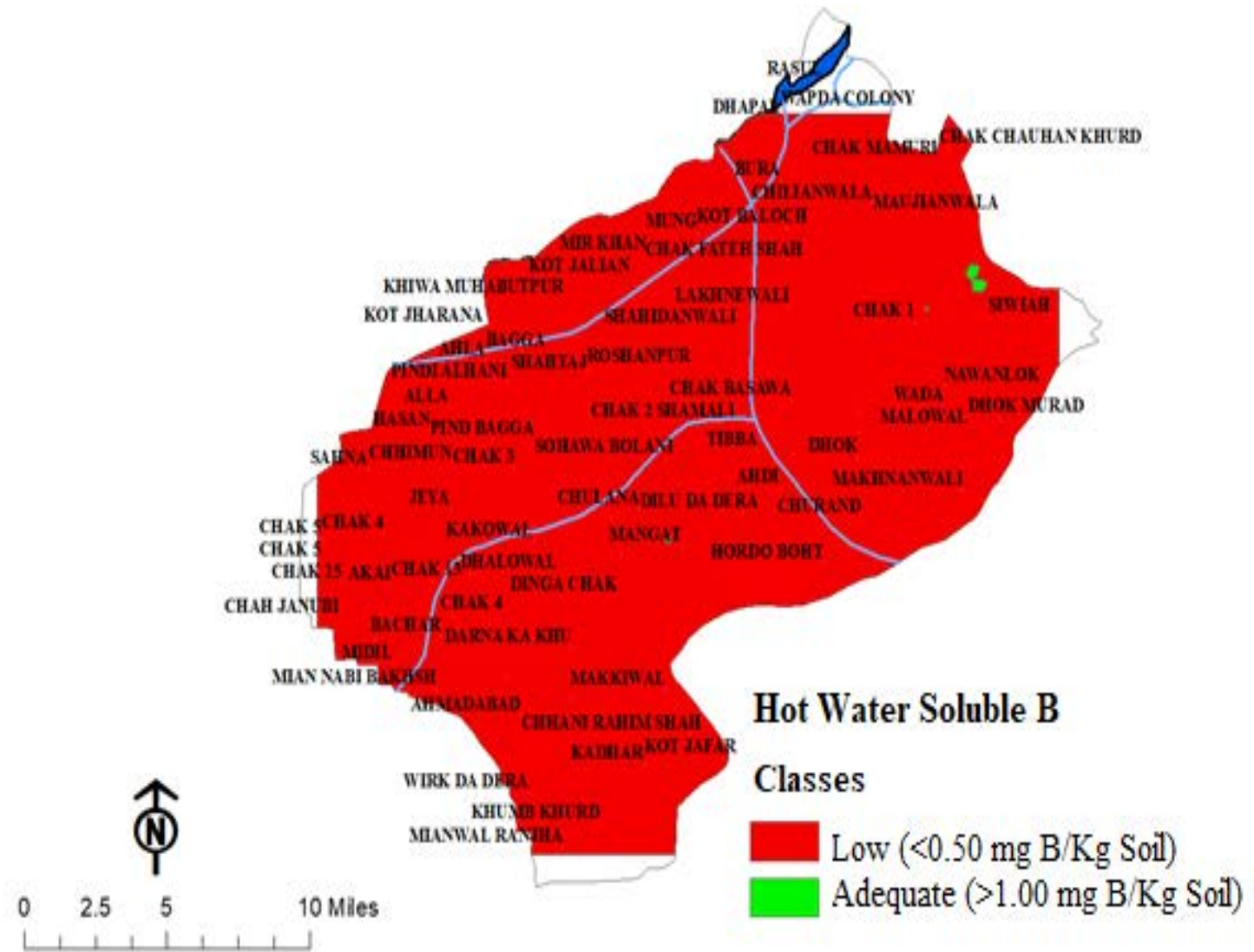

Figure 6: Distribution pattern of hot water-soluble boron in district Mandi Bahauddin. 
Soil salinity and sodicity appraisal

The electrical conductivity (EC) and soil $\mathrm{pH}$ values of soil samples were used to evaluate the salinity and sodicity status, respectively. The $\mathrm{EC}$ values fall between 0.10 and $3.74 \mathrm{dS} / \mathrm{m}$ and soil $\mathrm{pH}$ fall between 6.70 and 8.40 (Table 3). Considering the guideline criteria of NARC, Islamabad, all the soil samples were free from salinity and sodicity problem (Table 2).

\section{Soil organic matter status}

Soil organic matter ranged from 0.31 to $0.93 \%$ (Table 3). Analysis data revealed that $98 \%$ of soil samples were low in SOM whereas, $2 \%$ samples fall in marginal category regarding SOM (Table 2). Depletion of SOM in arid climatic conditions under intensive cropping system is a major problem hampering the crop yield (Sarwar et al., 2008).

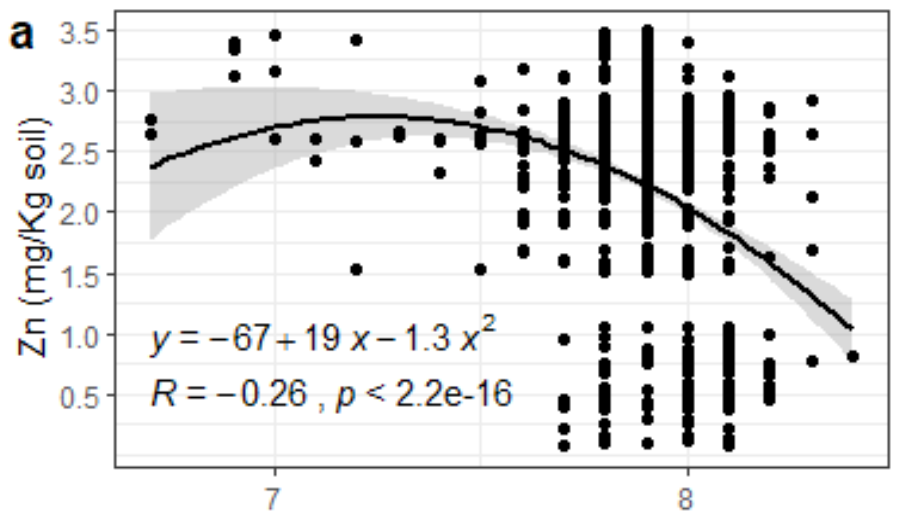

Soil pH

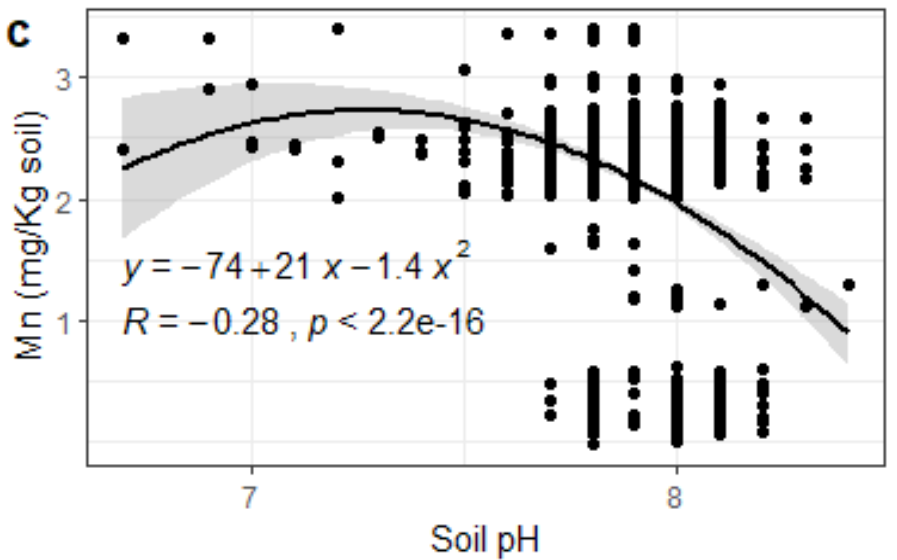

\section{Soil texture}

The textural class of soil sample ranged from sandy loam to loam which showed soil is suitable for cultivation of all types of crops (Table 3).

Correlation between soilcharacteristics and micronutrients Soil $\mathrm{pH}$ was negatively correlated with plant available $\mathrm{Zn}(\mathrm{R}=-0.26), \mathrm{Fe}(\mathrm{R}=-0.19), \mathrm{Mn}(\mathrm{R}=-0.28)$, and $\mathrm{B}(\mathrm{R}=-0.19)$ (Table 4, Figure 7). These correlations were significant and explained 26\%, 19\%, 28\% and $19 \%$ of variation in $\mathrm{Zn}, \mathrm{Fe}, \mathrm{Mn}$, and $\mathrm{B}$, respectively. The similar negative correlations between soil $\mathrm{pH}$ and bioavailable $\mathrm{Fe}$ and $\mathrm{Mn}$ were reported by Liu et al. (2004) in Pinghu county of south-east China.

The correlation between SOM and B was negative and explained $9 \%$ of variation in B (Table 4 ).

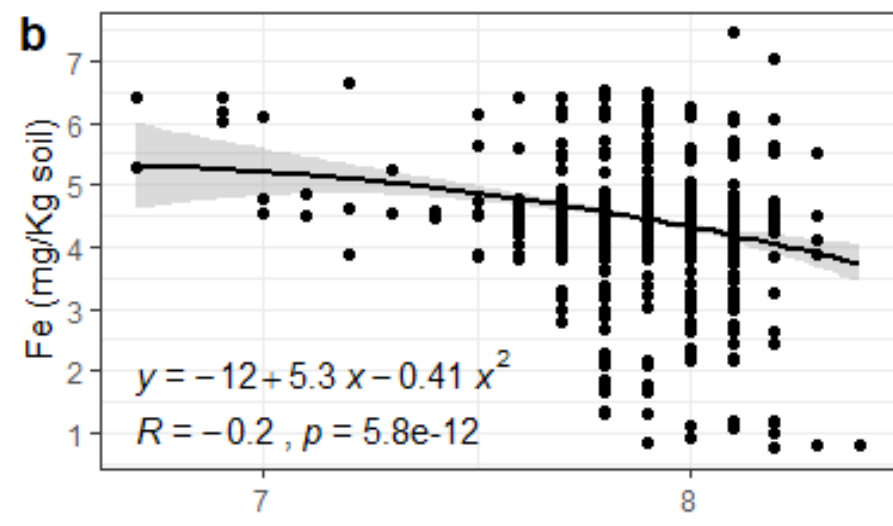

Soil pH

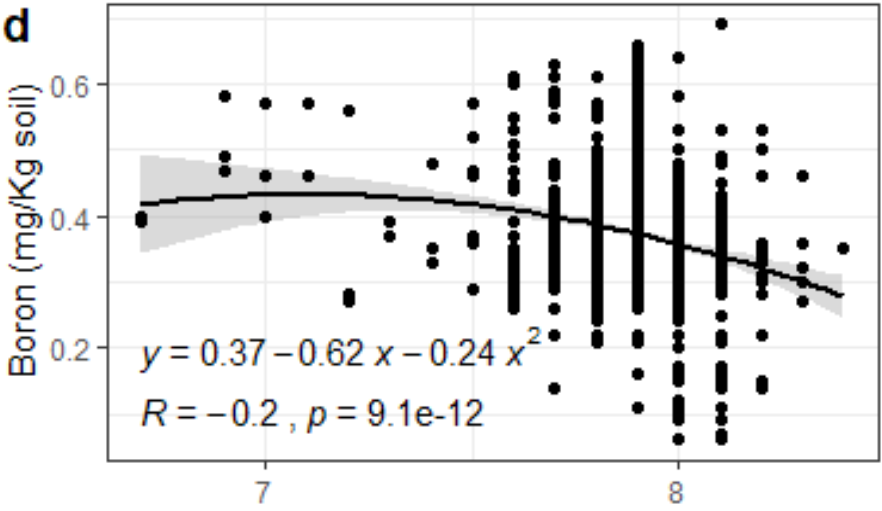

Soil pH

Figure 7: Regression models (polynomial) between Soil pH and (a) $\mathrm{Zn}$ (b) $\mathrm{Fe}$ (c) $\mathrm{Mn}$ and (d) B. Grey shades represent standard error.

\section{Conclusions and Recommendations}

Our study did not indicate any geographical trend of spatial distribution of plant available micronutrients in district Mandi Bahauddin. Overall status of plant available $\mathrm{Zn}$ and $\mathrm{Mn}$ were adequate whereas $\mathrm{Cu}$ was marginal in the study area. The widespread deficiency of $\mathrm{Fe}$ and $\mathrm{B}$ was concluded in this research work.
The significant negative correlations between soil $\mathrm{pH}$ and availability of micronutrients such as $\mathrm{Zn}, \mathrm{Fe}$, $\mathrm{Mn}$, and $\mathrm{B}$ were determined in the study area. These micronutrients become less available to plants at higher (alkaline) pH. Most of the agricultural soils of Pakistan are alkaline and calcareous in nature which could cause micronutrients deficiency if not managed wisely. The suitable nutrient management strategy 
could be the site-specific application of agricultural inputs. The spatial distribution maps developed in this research work could be helpful for policy makers, progressive farmers, researchers, and agricultural extension workers to make informed and site-specific decisions. Further studies are suggested to incorporate the temporal variation in the field data through random sampling and resultantly upgradation of prediction maps.

\section{Acknowledgement}

We are thankful to the Government of the Punjab, Agriculture Department for funding the project "Extension Service 2.O- Farmer Facilitation through Modernized Extension". The georeferenced soil samples were collected and analyzed under the said project.

\section{Author's Contribution}

Zahid Hassan Tarar conceived the idea and wrote the $1^{\text {st }}$ draft of manuscript. Dr. Shahzada Munawar Mehdi supervised the project and provided technical and financial support to run the project successfully. Muhammad Saleem, Irfan Ahmad Saleem, Raza Salim, Munir David and Mrs Saima Nazar collected geo-referenced soil samples $(\mathrm{n}=1194)$, analysed in laboratories and wrote up the methodology section related to their analysis. Muhammad Sufyan Mughal, Muhammad Salik Ali Khan, Tahir Majeed thoroughly checked the data, developed the location map, spatial distribution maps using QGIS software and wrote up the relevant methodology section. Muhammad Salik Ali Khan submitted the manuscript as corresponding author. Umer Iqbal prepared the correlation figures in revised manuscript using $\mathrm{R}$ language. Muhammad Khalid Shaheen and Muhammad Mazhar Iqbal edited and revised the manuscript as per reviewers' comments.

\section{Conflict of interest}

The authors have declared no conflict of interest.

\section{References}

Ahmad, H., M. Siddique and I. Hafiz. 2010. Zinc status of apple orchards and its relationship with selected physico-chemical properties in murree tehsil. Soil Environ. 29: 142-147.

Ahmed, H., M.T. Siddique, S. Ali, N.A. Abbasi, A. Khalid and R. Khalid. 2014. Micronutrient indexing in the apple orchards of northern punjab, pakistan using geostatistics and gis as diagnostic tools. Soil Environ. 33.

Arnon, D.I. and P. Stout. 1939. The essentiality of certain elements in minute quantity for plants with special reference to copper. Plant Physiol. 14: 371. https://doi.org/10.1104/pp.14.2.371

Bashir, E.L. and R. Bantel. 2005. Soil science. National Book Foundation, Islamabad, Pakistan.

Bell, P.F., B.R. James and R.L. Chaney. 1991. Heavy metal extractability in long-term sewage sludge and metal salt-amended soils. J. Environ. Q. 20: 481-486. https://doi.org/10.2134/ jeq1991.00472425002000020023x

Cresser,M.,K.Killham,T.Edwards and A.Edwards. 1993. Soil chemistry and its applications. Cambridge University Press. https://doi. org/10.1017/CBO9780511622939

Cressie, N., 1990. The origins of kriging. Math. Geol., 22: 239-252. https://doi.org/10.1007/ BF00889887

Fisk, L., L. Barton, D. Jones, H. Glanville and D. Murphy. 2015. Root exudate carbon mitigates nitrogen loss in a semi-arid soil. Soil Biol. Biochem. 88: 380-389. https://doi. org/10.1016/j.soilbio.2015.06.011

GOP, 2018. Extension service 2.O; farmer facilitation through modernized extension. Agriculture Department, Government of the Punjab, Pakistan. Available at http://ext. agripunjab.gov.pk/ongoing_projects [verified 03 May 2020]

Ihaka, R. and R. Gentleman. 1996. R: A language for data analysis and graphics. J. Comput. Graph. Stat. 5: 299-314. https://doi.org/10.10 80/10618600.1996.10474713

Khalil-ur-Rehman, K.J., M. Tunio and Z. Kuthu. 2009. Passive surveillance of gastrointestinal parasites in bufflaoes of mandi bahauddin and gujrat districts of the punjab. J. Anim. Plant Sci. 19: 17-19.

Khan,M.S.A.,M.A. Qazi, N. Khan, S.Mian and N. Ahmed. 2013. Comparison of three analytical methods for separation of mineral and chelated fraction from an adulterated zn-edta fertilizer.J. Chem. Soc. Pak. 35: 345-347.

Khan, M.S.A., M. Akram and M. Qazi. 2010. Calibration of shahid's analytical method for adulterated zn-edta fertilizers by ion chromatography and atomic absorption 
spectroscopy. J. Chem. Soc. Pak. 32: 613-619.

Khan, M.S.A., S.M. Mehdi, A.A. Sheikh, A.G. Khan, M. Shakar, A. Alvi, H.R. Ahmad and M. David. 2018. Delineation of nutrient management zones in chunian using soil attributes database developed by soil fertility research institute, punjab, pakistan. Soil Environ. 37: 116-122.

Lindsay, W.L. and W. Norvell. 1978. Development of a dtpa soil test for zinc, iron, manganese, and copper 1. Soil Sci. Soc. Am. J. 42: 421-428. https://doi.org/10.2136/ sssaj1978.03615995004200030009x

Liu, X., J. Xu, M. Zhang, J. Huang, J. Shi and X. Yu. 2004. Application of geostatistics and gis technique to characterize spatial variabilities of bioavailable micronutrients in paddy soils. Environ. Geol. 46: 189-194. https://doi. org/10.1007/s00254-004-1025-0

Marschner, P., 2012. Marschner's mineral nutrition of higher plants. Third Edition. Academic press, United States of America.

Meena, H., R. Sharma and U. Rawat. 2006. Status of macro-and micronutrients in some soils of tonk district of rajasthan. J. Indian Soc. Soil Sci. 54: 508.

Mortvedt, J.J., F.R. Cox, L.M. Shuman and R.L. Welch. 1991. Micronutrients in agriculture. Second Edition. Soil Sci. Soc. Am. Inc. Madison, Wisconsin, USA, Mexico.

Narwal, R. and B. Singh. 1998. Effect of organic materials on partitioning, extractability and plant uptake of metals in an alum shale soil. Water, Air, Soil Pollut. 103: 405-421. https:// doi.org/10.1023/A:1004912724284

Nazif, W., S. Perveen and I. Saleem. 2006. Status of micronutrients in soils of district bhimber (azad jammu and kashmir). J. Agric. Biol. Sci.
1:35-40.

Rashid, A., E. Rafique and N. Bughio. 1997. Micronutrient deficiencies in rainfed calcareous soils of pakistan. Iii. Boron nutrition of sorghum. Commun. Soil Sci. Plant Anal. 28: 441-454. https://doi.org/10.1080/00103629709369802

Rashid,A.,E.Rafique,N.Bughio and M.Yasin.1997. Micronutrient deficiencies in rainfed calcareous soils of pakistan. Iv. Zinc nutrition of sorghum. Commun. Soil Sci. Plant Anal. 28: 455-467. https://doi.org/10.1080/00103629709369803

Rayment, G.E. and D.J. Lyons. 2011. Soil chemical methods: Australasia. CSIRO publishing. https://doi.org/10.1071/9780643101364

Rengel, Z., 1999. Mineral nutrition of crops: Fundamental mechanisms and implications. CRC Press.

Ryan, J., G. Estefan and A. Rashid. 2001. Soil and plant analysis laboratory manual, international centre for agricultural research in the dry areas (icarda). Aleppo Natl. Agric. Res. Centre (NARC), Islamabad, Pakistan.

Sarwar, G., H. Schmeisky, N. Hussain, S. Muhammad, M. Ibrahim and E. Safdar. 2008. Improvement of soil physical and chemical properties with compost application in ricewheat cropping system. Pak. J. Bot. 40: 275-282.

Tisdale, S.L., W.L. Nelson and J.D. Beaton. 1985. Soil chemistry and its applications. Cambridge Univ. Press.

William-Horwitz, G.L., 2005. Official methods of analysis of aoac international. $18^{\text {th }}$ edition, 2005, current through revision, 4, 2011. Method no. 2.6.04 (aoac official method 985.01).

Zia, M., R. Ahmad, I. Khaliq, A. Ahmad and M. Irshad. 2006. Micronutrients status and management in orchards soils: Applied aspects. Soil Environ. 25: 6-16. 